\title{
KARAKTERISTIK BUDAYA KOMUNIKASI POLITIK ELITE MUHAMMADIYAH
}

\section{Pia Khoirotun Nisa}

STIT Al Amin Banten

piakhoiritunnisa@gmail.com

\begin{abstract}
:
Muhammadiyah is one of the elements from the public room of Indonesia, it accepts amount of political policies from the power of nation and responses them as the tradition of its organization. The special characteristic of organization determines political communication that is used. In doing political communication, the political elite of Muhammadiyah has to be able to play very important role in a political system because it becomes determined part from the process of political socialization, political culture, political participation and political recruitment.
\end{abstract}

Keywords: Organization, Characteristic, Political Elite. 


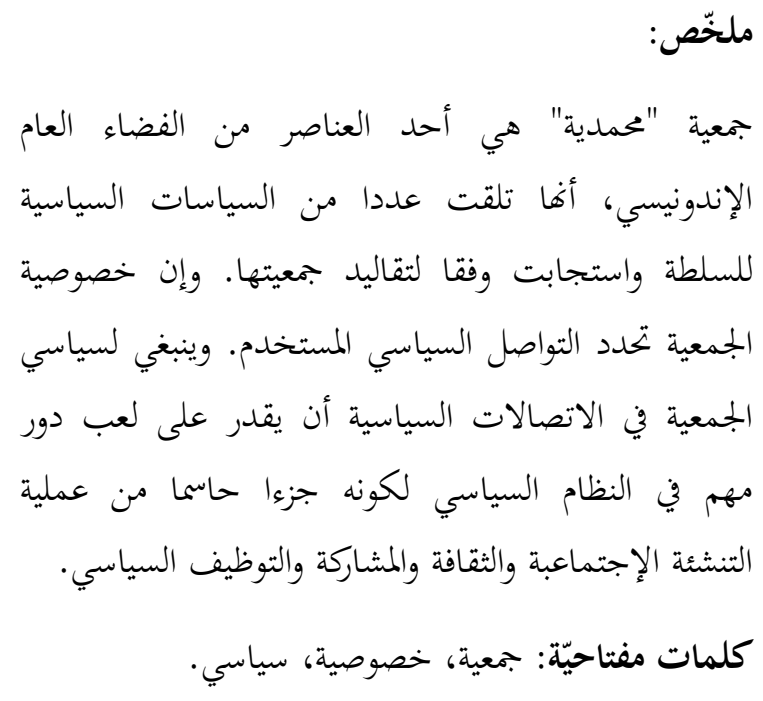

\section{A. Pengaruh Otoritas Elite dalam Budaya Politik Muhammadiyah}

Melacak akar budaya dan basis komunikasi Muhammadiyah, dapat dicermati dari keberadaan organisasi Islam ini yang menurut James $\mathrm{L}$. Peacock telah menjadi sebuah pergerakan Islam yang terkuat di Asia Tenggara. ${ }^{1}$ Sementara itu, Nurcholish Madjid menilai bahwa Muhammadiyah sebagai organisasi Islam 'modern' terbesar di dunia lebih daripada yang mana pun di negeri-negeri Islam lain. ${ }^{2}$

Secara organisatoris, Muhammadiyah sebagai gerakan dakwah berjuang di lapangan (cultural) masyarakat, bukan struktural politik, bahkan organisasi politik. Namun sejak era KH. Ahmad Dahlan (1868-1923). ${ }^{3}$ Muhammadiyah tak pernah lepas sama sekali dari politik, hal ini disebabkan

1 James L. Peacock, Gerakan Muhammadiyah Memurnikan Ajaran Islam di Indonesia, (Jakarta: Cipta Kreatif, 1986), h. 26.

2 Nurcholish Madjid, Aqidah Islam Yang perlu Dikembangkan Sebagai Landasan Pemikiran dan Amal Muhammadiyah, dalam Sujarwo (dkk) Muhammadiyah dan Tantangan Masa Depan: Sebuah Dialog Intelektual, (Yogyakarta: Tiara Wacana, 1990), h. 407.

3 Sutrisno Kutoyo, Kiai Haji Ahmad Dahlan dan Persyarikatan Muhammadiyah, (Jakarta: Balai Pustaka, 1998), h. 76.

$100 \mid$ Jurnal a l-Amin, Volume 3, No 1, 2015 M/1436 H 
karena Kiai Dahlan sendiri selain pendiri, sekaligus juga ketua Muhammadiyah, adalah termasuk penggerak Budi Utomo yang merupakan pionir gerakan politik kalangan nasionalis dan Serikat Islam (SI) yang merupakan pionir gerakan politik kalangan Islam, dua organisasi yang menjadi gerakan pionir di zaman kolonial. Sepanjang kepemimpinannya, Kiai Dahlan tidak pernah merumuskan "ideologi politik" Muhammadiyah. Ia tidak pernah merumuskan bagaimana seharusnya Muhammadiyah memandang politik, apalagi berpolitik, Muhammadiyah tidak didesain untuk politik.

Sebenarnya dari referensi-referensi internal Muhammadiyah, pasca KH. Ahmad Dahlan, ada dua tokoh yang amat menonjol yaitu H. Fakhruddin (1890-1929) dan KH. Mansur (1896-1946), terutama dalam perilaku politiknya berhadapan dengan Belanda dan Jepang, sehingga keduanya diangkat sebagai pahlawan nasional oleh Republik Indonesia tahun 1964.

Hubungan Muhammadiyah dengan politik tampak signifikan pada saat di bawah kepemimpinan KH. Mas Mansyur. Mas Mansyur adalah inisiator utama kelahiran Majelis Islam A'la Indonesia (MIAI) tahun 1937, yang bobot politiknya sangat besar bagi perjuangan umat Islam saat itu. Selain itu, pada tahun 1938, Mas Mansyur juga menjadi salah seorang tokoh Partai Islam Indonesia (PII). Karena langkah-langkah politiknya ini, Ahmad Syafii Ma'arif menjuluki Mas Mansyur sebagai 'pendiri kedua' Muhammadiyah, dalam arti telah memberikan warna politik pada gerakan Islam ini. Dengan kata lain, Mas Mansurlah yang pertama-tama merumuskan ideologi politik Muhammadiyah, yakni semacam pandangan politik dan sekaligus pedoman bagaimana mestinya warga Muhammadiyah berpolitik. Baru setelah itu, dalam setiap Muktamar atau Tanwir dirumuskan sikap-sikap politik Muhammadiyah.

Secara formal organisasional, Muhammadiyah sejak lama memiliki rumusan tentang fatsun (kesopanan) politiknya. Ketika Mas Mansyur mengundurkan diri dari Ketua Umum Partai Islam Indonesia (PII), sekaligus merangkap sebagai ketua PP Muhammadiyah, itu merupakan fatsun politik. Demikian juga ketika dia mengusulkan rumusan yang kemudian disetujui Tanwir 1939 bahwa: 
Bagi Muhammadiyah, (1) Politik itu Penting, tetapi (2) tidak menjadi bidang garapan Muhammadiyah. Dan jika orang Muhammadiyah ingin berjuang di bidang itu, (3) harus dibuat wadah atau lembaga tersendiri yang (4) berada di luar organisasi Muhammadiyah, tetapi (6) harus bisa bekerja sama. Dan last but not least, dalam mengembangkan lembaga atau wadah politik tersebut harus bekerja sama dengan kekuatan umat lainnya.

Di zaman Jepang Muhammadiyah dengan tokoh Mas Mansur, bersama Soekarno, Moh Hatta dan Ki Hadjar Dewantara merupakan empat serangkai. ${ }^{4}$ Keempat tokoh ini sangat dipercaya dan suaranya didengar oleh rakyat, dan mereka diserahi untuk memimpin organisasi baru yang disebut Pusat Tenaga Rakyat (PUTERA), didirikan tanggal 9 Maret 1943. Maksud dari organisasi ini adalah untuk membujuk bangsa Indonesia supaya lebih banyak mengabdikan diri kepada Jepang. Tampilnya Mas Mansur dalam empat serangkai ini merupakan tanda pengakuan pihak nasionalis serta pihak Jepang tentang pentingnya kedudukan umat Islam dalam panggung politik Indonesia.

Pada era Orde Lama, terutama pada masa-masa awal pembentukan karakter bangsa (nation's character building), langkah-langkah politik Muhammadiyah direpresentasikan oleh tokoh-tokohnya antara lain Abdul Kahar Muzakkir (1907-1973), Kasman Sigodimendjo, dan Ki Bagus Hadikusuma (1890-1954), tiga tokoh yang sangat berpengaruh bagi lahir dan dihapuskannya 'Piagam Jakarta'.

Ada periode awal rezim Orde Baru, elite Muhammadiyah membidani kelahiran Partai Muslimin Indonesia (Parmusi) pada 20 Februari 1968. Dua elite Muhammadiyah, Djarnawi Hadikusuma (Ketua Umum), waktu itu Ketua Majelis Hikmah PP Muhammadiyah, dan Lukman Harun (Sekretaris Jenderal), memimpin Parmusi hingga kemudian dikudeta oleh J. Naro dan Imran Kadir yang membentuk kepemimpinan tandingan, masing-masing sebagai ketua umum dan sekretaris umum, pada tahun 1970.

Rezim Orde Baru memberlakukan kebijakan depolitisasi Islam yang ditandai, terutama dengan penyatuan

4 Delier Noer, The Modernist Muslim Movement in Indonesia 1900-1904, (London: Oxford University Press, 1973), h. 85.

102| Jurnal a l-Amin, Volume 3, No 1, 2015 M/1436 H 
(fusi) partai-partai politik Islam dan Partai Persatuan Pembangunan (PPP) tahun 1973. Tak ada langkah politik Muhammadiyah yang signifikan hingga Tanwir 1993 di Surabaya, ketika Amin Rais waktu itu wakil ketua PP Muhammadiyah mengajukan gagasan perlunya suksesi kepemimpinan nasional. Meskipun gagasan itu urung menjadi rekomendasi Tanwir, namun menjadi wacana nasional.

Ketika KH. Ahmad Azhar Basyir, MA (1990-1995) wafat tanggal 28 Juni 1994, Amin Rais tampil sebagai tokoh pucuk Muhammadiyah. Sejak saat itulah, tarikan politik dalam Muhammadiyah kembali menguat. Dalam banyak kesempatan, di samping banyak mengkritik kebijakankebijakan politik Soeharto, Amin Rais juga senantiasa menyuarakan kembali perlunya kepemimpinan nasional, dia juga senantiasa menyuarakan kembali perlunya kepemimpinan nasional. Kabarnya, Soeharto marah besar sehingga ia berupaya agar 'musuh' nya itu tak terpilih dalam Muktamar Muhammadiyah ke 48 tahun 1995 di Banda Aceh tetapi upayanya gagal dan rais terpilih dengan meraih suara hampir seratus persen. ${ }^{5}$

Sebagai ketua PP Muhammadiyah, Amin Rais tak henti-hentinya mengkritik Soeharto, sehingga gerakan reformasi politik tahun 1998, alumnus Universitas Chicago, AS, ini dianggap sebagai motor utamanya, dan sejumlah mahasiswa menobatkannya sebagai 'Bapak Reformasi'. Kepeloporan Amin Rais menggerakkan reformasi hingga Soeharto lengser dari singgasananya, 21 Mei 1998. Bukan tanpa risiko. Sejumlah tokoh reformis lain mendorong Amin Rais mendirikan partai politik untuk menjadi 'kendaraan politik' baginya untuk tampil ke kursi kepresidenan, menuntaskan gerakan reformasi. Kuatnya dorongan pada Rais itu berdampak langsung pada Muhammadiyah, sehingga Tanwir tahun 1998 di Semarang antara lain memberikan izin kepada Amin Rais untuk mendirikan Partai Amanat Nasional (PAN), 23 Agustus 1998.

Keterlibatan aktif Muhammadiyah dalam persoalan kebangsaan sejak berdiri hingga sekarang harus diletakkan dalam proses sejarah Indonesia. Taufik Abdullah menyatakan, bahwa “... Muhammadiyah hanya mungkin

5 M. Cholil Bisri, Nahdlatul Ulama: Proses Kristalisasi atau Ketuaan, dalam Wahid, (Republika: t.p., 1995), h. 23. 
dapat dipahami kalau sejarah ditempatkan dalam konteks dinamika hubungan masyarakat dan negara di tanah air". ${ }^{6}$

Penilaian Taufik Abdullah ini menunjukkan bahwa Muhammadiyah tidak bisa dilepaskan sama sekali dari hubungan antara Islam dengan politik di Indonesia, bahkan Muhammadiyah merupakan mata rantai dari kebangkitan nasional pada abad XX, ${ }^{7}$ diawali dengan lahirnya Budi Utomo pada tanggal 20 Mei 1908. ${ }^{8}$ Bangkit kembali semangat dan jiwa patriotik segenap kekuatan nasional progresif yang bertekad meneruskan perjuangan menghadapi kekuatan dan kekuasaan kolonialisme, imperialisme, kapitalis Belanda, yang dalam bentuk konkritnya berwujud pemerintahan kolonial Hindia Belanda. Muhammadiyah lahir untuk menghadapi kolonialisme dan imperialisme Belanda di Indonesia. H. A. Mukti Ali mempertegas bahwa lahirnya Muhammadiyah disebabkan adanya penetrasi bangsa-bangsa Eropa. ${ }^{9}$

Sejarah keterlibatan Muhammadiyah dalam pergerakan nasional diawali pada tahun 1918 Muhammadiyah mendirikan kepanduan yang diberi nama Hizbul Wathon (HW) yang artinya pembela tanah air. Dalam kepanduan HW ini ditanamkan kesadaran berbangga dengan rajin oleh $\mathrm{KH}$. Ahmad Dahlan, cinta tanah air, disiplin, kerja keras, ikhlas dalam berjuang, sekaligus ditingkatkan kualitas keimanan dan ketakwaan kepada Allah Swt. Imbasnya, sepanjang sejarahnya, dapat dikatakan Muhammadiyah belum pernah mengalami prahara politik intern yang berimbas perpecahan. Hal ini lantaran sikapnya yang independen dan ekstra hatihati dalam menghadapi dan berurusan dengan masalah politik praktis yang didasarkan pada kepentingan. Realita ini

6 Taufik Abdullah, Muhammadiyah dalam Perspektif Sejarah, dalam Tim Pembina al-Islam dan Kemuhammadiyahan, Muhammadiyah: Sejarah, Pemikiran dan Amal Usaha, (Malang: Pusat Dokumentasi dan Publikasi Universitas Muhammadiyah Malang, 1990), h. 58.

7 M. Daris Tamim, Muhammadiyah di Mata Rantai Perjalanan Bangsa, dalam Suara Muhammadiyah, No. 22/67 tahun 1987, h. 35-38.

8 M. A. Gani, Cita Dasar Pola Perjuangan Syarikat Islam, (Jakarta: Bulan Bintang, 1984), h. 9.

9 A. Mukti Ali, Interpretasi tentang Amalan Muhammadiyah, dalam Pegangan Instruktur Kaderisasi Pemuda Muhammadiyah, (Jakarta: Pimpinan Pusat Pemuda Muhammadiyah, 1982), h. 7-27.

104| Jurnal a 1-Amin, Volume 3, No 1, 2015 M/1436 H 
terlihat ketika K.H. Ahmad Dahlan dipercaya untuk menjadi pengurus Sarekat Islam (SI) dan Budi Utomo (BU), ia tidak membawa dampak politik yang berarti bagi Muhammadiyah, karena itu inisiatif pribadi, bukan perserikatan. Demikian halnya ketika Mas Mansur menduduki jabatan penting di Partai Islam Indonesia (PII), tidak banyak pengaruhnya bagi gerak langkah Muhammadiyah. ${ }^{10}$

Pada tahun 1945, perhatian Muhammadiyah terfokus pada upaya meraih kemerdekaan bangsa dari penjajah. Beberapa tokohnya, antara lain Ki Bagus Hadikusumo, Mr. Kasman Singodimedjo, Prof. Kahar Mudzakir menjadi anggota Panitia Persiapan Kemerdekaan Indonesia (PPKI), dan mempersiapkan Undang-Undang Dasar, yang sekarang dikenal dengan nama UUD 1945. Generasi mudanya diinstruksikan mempersiapkan secara fisik, untuk bertempur melawan musuh dengan membentuk Laskar Hizbullah dan Barisan Sabilillah di tiap-tiap daerah di seluruh Indonesia. Muhammadiyah ikut dalam gelombang pasang surutnya perjuangan kemerdekaan, menghadapi kolonialisme asing dan militerisme Jepang. ${ }^{11}$ Selain itu, Muhammadiyah juga terlibat aktif dalam pergerakan untuk menumpas gerakan komunisme di Indonesia.

Sejak pasca Proklamasi sampai dengan tahun 1990, Muhammadiyah dalam penyaluran aspirasi politiknya tidaklah independen. Terlebih pada masa Demokrasi Terpimpin (1950-1965), merupakan masa-masa sulit dan kritis bagi Muhammadiyah. ${ }^{12}$ Di akhir 1960, Masyumi bubar, akibatnya Muhammadiyah kehilangan wadah politiknya. Masa-masa sulit ini akhirnya memaksa Muhammadiyah untuk tampil sebagai organisasi masyarakat yang menjalankan politik praktis (ormaspol) dengan segala dampaknya yang lebih banyak negatif. Beberapa tokoh Muhammadiyah pada masa itu diangkat menjadi anggota Dewan Perwakilan Rakyat Gotong Royong (DPRGR) bentukan

10 Ahmad Syafii Ma'arif, Independensi Muhammadiyah: Di Tengah Pergumulan Pemikiran Islam dan Politik, (Jakarta: Cidesindo, 2000), h. 86.

11 Roeslan Abdulgani, Peranan Muhammadiyah Dalam Pergerakan Nasional dan Kemungkinan Masa Depannya, dalam M. Yunan Yusuf, Cita dan Citra Muhammadiyah, (Jakarta: Pustaka Panjimas, 1985), h. 63.

12 Haedar Nasir, Revitalisasi Gerakan Muhammadiyah, (Yogyakarta: BIGRAF Publishing, 2000), h. Xiii. 
Presiden Soekarno. Di antranya adalah Djarnawi Hadikusumo, Lukman Harun, Djasman al-Kindi, Daris Tamim, Abdul Mukti, A. Wahab Radjab, H. Kamawidjaya. Kemudian Muhammad Mawardi, yang diangkat menjadi anggota DPRGR mewakili Muhammadiyah. ${ }^{13}$

Dalam realitasnya, tradisi komunikasi Muhammadiyah sangat kuat mempengaruhi pola komunikasi warga Muhammadiyah. Baik dalam konteks formal maupun informal. Selain itu, saluran komunikasi masih bertumpu pada bentuk face-to-face communication, sehingga sering terjadi keterlambatan dan keterhambatan di lingkungan Muhammadiyah. Diantara kelebihan bentuk komunikasi ini, seperti terjadi pada umumnya kaum Muhammadiyah, adalah kedekatan emosional yang lebih dominan mempengaruhi jalannya komunikasi.

Selain itu, saluran komunikasi politik Muhammadiyah dapat diamati melalui keterlibatannya dalam dunia politik praktis menyiratkan fenomena politisasi. Agama ditandai, digunakan isu agama, baik sebagai simbol pesan-pesan maupun sebagai salah satu bentuk saluran potensial komunikasi politik Muhammadiyah. Wacana agama menjadi kemasan yang dominan dalam proses komunikasi politik yang diperankan Muhammadiyah. Sebagai organisasi sosial keagamaan, pesan-pesan komunikasi politik Muhammadiyah memberikan kesan kuat sebagai pesan-pesan agama yang disampaikan melalui proses simbolisasi politik dalam nuansa agama.

Hal tersebut mampu memberikan efek yang mudah diterima massa, karena proses pembentukan suasana yang dipandang relevan dengan suasana psikologis setiap partisipan komunikasi yang terlibat. Sebab dalam komunikasi pesan juga bergantung pada konteks fisik atau ruang, waktu, sosial dan psikologis. ${ }^{14}$ Demikian juga figur komunikator yang menjadi juru bicara utama komunikasi politik Muhammadiyah hampir selalu memperlihatkan warna ganda yang diperankannya, antara pemimpin politik dan pemimpin agama.

13 Ahmad Syafii Ma'arif, Independensi Muhammadiyah: Di Tengah Pergumulan Pemikiran Islam dan Politik, (Jakarta: Cidesindo, 2000), h. 86-87.

14 Deddy Mulyana, Komunikasi Politik: Suatu Pengantar, (Bandung: Rosda, 2001), h. 103.

106| Jurnal a l-Amin, Volume 3, No 1, 2015 M/1436 H 
Dalam hal ini, agama menjadi simbol yang dapat melicinkan proses komunikasi untuk menemukan kesamaan-kesamaan rujukan dan pengalaman diantara pihak-pihak yang terlibat dalam proses komunikasi. Sebab sebagai animal symbolicum yang dalam hal ini ditegaskan Ernest Gassier yang menyatakan bahwa diantara keunggulan manusia atas makhluk lainnya adalah karena keistimewaannya sebagai animal symbolicum. Karena kebutuhan simbolisasi atau penggunaan lambang, Susanne K Langer, merupakan salah satu kebutuhan pokok manusia. Manusia memang satu-satunya hewan yang menggunakan lambang, dan itulah yang membedakan manusia dari makhluk lainnya. ${ }^{15}$ Lambang atau simbol seperti apa yang dikatakan Dedy Mulyana adalah sesuatu yang digunakan untuk menunjuk sesuatu yang lainnya. Berdasarkan kesepakatan sekelompok orang. Dia meliputi kata-kata (pesan verbal), perilaku (pesan non-verbal), dan objek-objek yang maknanya disepakati bersama. ${ }^{16}$

Relasi agama, komunikasi politik, dan aktor politik kaum Muhammadiyah dapat merujuk pada perspektif interaksi simbolik yang diperkenalkan George Herbert Mead, bahwa perilaku manusia muncul melalui proses pemaknaan terhadap objek di sekitarnya. Prinsip ini kemudian dijelaskan Dedy Mulyana bahwa orang-orang sebagai peserta komunikasi (communicators) bersifat aktif, reflektif dan kreatif dalam menafsirkan, menampilkan perilaku yang rumit dan sulit diramalkan. ${ }^{17}$

Dari apa yang telah dipaparkan di atas penulis menegaskan pemetaan komunikasi politik elite Muhammadiyah untuk mengeliminir adanya kesan umum sebagai perilaku Muhammadiyah yang inkonsisten. Menurut penulis, sebenarnya komunikasi politik Muhammadiyah tidak lebih dari proses pemaknaan terhadap isyarat-isyarat politik yang berlangsung secara aktif, reflektif, dan kreatif dalam ranah konstelasi politik yang berkembang dan bukan doktriner. Hal ini dibenarkan pada realitas politik

15 Deddy Mulyana, Komunikasi Politik: Suatu Pengantar, h. 83-84.

16 Deddy Mulyana, Komunikasi Politik: Suatu Pengantar, h. 84.

17 Deddy Mulyana, Komunikasi Politik: Suatu Pengantar, h. 160. 
Muhammadiyah yang mewarnai perubahan-perubahan politik yang melingkupinya.

Sementara pemaknaan agama yang digunakan Muhammadiyah tidak lebih sebatas untuk menjustifikasi perilaku tersebut muncul karena ketersediaan bahan rujukan yang dimiliki para pelaku politik itu serta kuatnya ikatan emosional dengan lambang-lambang agama yang telah akrab dalam kesadaran hidupnya.

\section{B. Basis Budaya Komunikasi Politik dalam Muhammadiyah}

Sebelum Dipaparkan dengan lugas budaya komunikasi politik dalam elite Muhammadiyah maka perlu dipahami terlebih dahulu mengenai bagaimanakah konsep budaya politik itu sendiri. Konsep budaya politik secara sederhana, mengandung arti budaya yang mempengaruhi politik. Budaya bisa diartikan cara hidup (the way of life) suatu masyarakat, yaitu suatu kompleksitas kepercayaan da perilaku masyarakat bertindak dalam berbagai bidang ketika masyarakat bertindak dalam bidang politik, mereka disebut sebagai 'masyarakat politik' (the polity). Dengan demikian, budaya politik mengacu pada aspek-aspek budaya yang berpengaruh dalam pembentukan masyarakat politik. ${ }^{18}$

Beberapa ilmuwan politik seperti Almond dan Verba mengartikan budaya politik sebagai sikap individu terhadap sistem politik dan komponen-komponennya, serta sikap individu terhadap peranan yang dapat dimainkannya dalam sebuah sistem politik. ${ }^{19}$ Lebih jauh budaya politik merupakan orientasi yang bersifat kejiwaan (psikologis) karena didasarkan pada sikap, nilai-nilai, informasi, dan kecakapan politik yang dimiliki individu. ${ }^{20}$ Kajian yang mereka lakukan menunjukkan adanya hubungan antara nilai-nilai budaya dengan sistem politik yang demokratis, sementara sistem nilai lainnya menopang sistem politik yang

18 Suwarno, Muhammadiyah Sebagai Oposisi, (Yogyakarta: UII Press Jogjakarta, 2001), h. 59.

19 Afan Gaffar, Budaya Politik Indonesia, Bahan Kuliah Analisa Politik Indonesia, (Yogyakarta: Program Pascasarjana Ilmu Politik UGM, 1998), h. 5.

20 Gabriel A. Almond, Sosialisasi, Kebudayaan dan Partisipasi Politik, dalam Mohtar Mas'oed dan Colin Mac Andrews (editor). Perbandingan Sistem Politik, (Yogyakarta: Gadjah Mada University Press, 1995), h. 41.

108| Jurnal a l-Amin, Volume 3, No 1, 2015 M/1436 H 
cenderung otoriter, meskipun ini tidak berarti budaya politik yang cenderung otoriter, meskipun ini tidak berarti budaya politik tertentu identik dengan sistem politik tertentu.

Sikap dan orientasi individu terhadap suatu sistem politik, selanjutnya membentuk budaya politik yang berbeda. Dalam hal ini terdapat tiga orientasi, yaitu kognitif, afektif, dan evaluatif. Orientasi kognitif berkaitan dengan pemahaman individu dan keyakinan terhadap sistem politik beserta atributnya seperti ibukota negara, lambing negara, kepala negara, dan lain-lain. Orientasi kognitif akan membentuk budaya politik parochial. Berikutnya orientasi aktif menyangkut ikatan emosional individu terhadap sistem politik, dan orientasi seperti ini akan membentuk budaya politik yang bersifat subjektif. Sementara itu, orientasi evaluatif berkenaan dengan kapasitas individu dalam membuat penilaian terhadap sistem politik yang sedang berjalan dan bagaimana peranan individu di sedang berjalan dan bagaimana peranan individu di dalamnya. Orientasi evaluatif ini akan membentuk budaya politik partisipan. Hubungan antara orientasi terhadap sistem politik dengan budaya politik di atas dapat dilihat pada tabel di bawah ini.

Tabel

Hubungan antara orientasi terhadap sistem politik dengan budaya politik ${ }^{21}$

\begin{tabular}{|l|c|c|c|}
\hline $\begin{array}{l}\text { Politik Budaya } \\
\text { Orientasi } \\
\text { terhadap sistem politik }\end{array}$ & Parokial & Subjektif & Partisipan \\
\hline Kognitif & $\mathrm{XXX}$ & & \\
\hline Afektif & & $\mathrm{XXX}$ & \\
\hline Evaluatif & & & $\mathrm{XXX}$ \\
\hline
\end{tabular}

Budaya politik parokial ditandai apabila sebagian besar individu atau warga negara memiliki pengetahuan tentang sistem politik yang sedikit, dan keterlibatannya dalam kegiatan politik rendah. Sistem politik dalam budaya politik parochial adalah sistem demokratis pra-industrial.

21 Diambil dari Afan Gaffar, Bahan Kuliah Analisa Politik Indonesia, h. 7 dan Afan Gaffar, Politik Indonesia Transisi Menuju Demokrasi, h. 100. 
Kemudian, budaya politik subjektif dimiliki oleh sistem politik yang otoriter semi industrial. Di sini individu atau warga negara menjadi subjek yang pasif, patuh pada pemerintah dan tunduk pada hukumnya, namun tidak melibatkan diri dalam urusan politik pemerintahan. Sedangkan budaya politik partisipan ditandai oleh keterlibatan sebagian besar individu atau warga negara dalam kegiatan politik. Budaya politik partisipan dimiliki oleh masyarakat industrial dengan sistem politik yang demokratis. ${ }^{22}$

Budaya politik biasanya dibagi dalam dua kategori, yaitu budaya politik elite dan budaya politik massa. Budaya politik elite melibatkan sikap dan pola tingkah laku mereka yang mempunyai peranan aktif dan pengaruh dalam sistem politik. Sebaliknya, budaya politik massa dibentuk oleh sikap dan orientasi terhadap politik rakyat secara keseluruhan, termasuk partisipasi mereka dalam kegiatan politik. Sebaliknya budaya politik massa dibentuk oleh sikap dan orientasi terhadap politik rakyat secara keseluruhan termasuk partisipasi mereka dalam kegiatan politik. Dalam penelitian ini, budaya komunikasi politik elite lebih diutamakan dibandingkan dengan budaya komunikasi politik massa karena perubahan perilaku politik di dalam Muhammadiyah di sini beroperasi pada dataran elite.

Budaya politik Muhammadiyah merupakan bagian dari (sub) budaya politik nasional bangsa Indonesia. Selama rezim Orde Baru yang otoritarian berkuasa, budaya politik Indonesia didominasi oleh sub budaya Jawa yang dapat dilihat dari semakin menguatnya nilai-nilai tradisional Jawa sebagai budaya politik nasional. Kenyataan ini tampak misalnya rekrutmen elite untuk jabatan semacam menteri lebih didasarkan pada loyalitas atau kedekatan hubungan daripada kapabilitas atau kemampuan. Di samping itu tampak dari pola hubungan kekuasaan patron-client (kawulogusti). Bahwa pejabat berkedudukan sebagai gusti (penguasa). Sementara rakyat hanya dipandang sebagai kawulo (yang dikuasai). Hubungan antara pejabat dengan rakyat dibingkai oleh sikap 'sungkan' dan ewuh-pakewuh.

22 Gabriel A. Almond, "Sosialisasi, Kebudayaan dan Partisipasi Politik" dalam Mohtar Mas'oed dan Colin Mac Andrews (editor), "Perbandingan Sistem Politik", (Yogyakarta: Gadjah Mada University Press, 1995), h. 42-43.

110 | Jurnal a l-Amin, Volume 3, No 1, 2015 M/1436 H 
Pendeknya, dominasi sub budaya Jawa terhadap budaya politik nasional telah membuat budaya politik Indonesia bersifat feodalisme. Dalam sifat feodal itu kecenderungan sangat kuat dimana prinsip 'daulat tuanku' berada di atas 'daulat rakyat'. Bahwa prinsip 'daulat rakyat' menjadi subordinasi tuanku'.23

Sebagai bagian dari gerakan Islam, budaya politik Muhammadiyah sesungguhnya merupakan bagian (sub) dari budaya politik Islam Indonesia. Budaya politik Islam Indonesia itu sendiri barangkali dapat dipilahkan dalam dua kategori besar, yaitu: 1). Budaya politik Islam modernis sebagaimana diwakili oleh Muhammadiyah, dan 2). Budaya politik Islam tradisionalis seperti diwakili oleh NU. Perbedaan diantara kedua kategori budaya politik Islam ini, selain terletak pada cara atau strategi yang dipakai, juga pada landasan teologis filosofinya. Bila Muhammadiyah condong bergerak lurus/hitam-putih/teguh pada prinsip dengan kecenderungan rasional karena ditopang oleh landasan teologis-filosofisnya sebagai gerakan pembaharuan atau pemurnian, maka NU lebih condong untuk bergerak secara berliku-liku/zig-zag/luwes dengan kecenderungan oportunis karena disokong oleh landasan teologis-filosofis yang serba fikih.

Budaya politik yang dikembangkan Muhammadiyah sejak awal dan masih relevan hingga kini adalah doktrin dakwah 'amar ma'rüf, nahyi munkar, yang melekat (inherent) pada definisi/identitas nama gerakan ini, sebagaimana tersebut pada Anggaran Dasar Muhamamdiyah bab 1 pasal 1. Hal ini berarti budaya politik Muhammadiyah disinari atau dibimbing oleh kepribadian Muhammadiyah. Doktrin dakwah 'amar ma'rūf dan nahyi munkar, diadopsi secara langsung dari QS. Âli 'Imrān ayat 104, yang sering dianggap sebagai ayat Muhammadiyah, yaitu:

"Dan hendaklah ada di antara kamu suatu kelompok umat (jamaah), yang menyeru manusia kepada kebajikan, menyuruh yang ma'ruf dan mencegah yang munkar, dan jamah seperti itulah yang mendapat kemenangan," (QS. Āli 'Imrān [3]: 104).

23 Kusnanto Anggoro, "Rekonstruksi dan Reorientasi Budaya Politik", dalam J. Soedrajati Djiwandono dan T. A. Legowo (Penyunting), "Revitalisasi Sistem Politik Indonesia", (Jakarta: CSIS, 1996), h. 209-210.

Jurnal al-Amin, Volume 3, No 1, 2015 M/1436 H | 111 
Doktrin dakwah 'amar ma'rūf dan nahyi munkar yang melekat pada Muhammadiyah itu dalam praksis-historisnya dikomunikasikan dan diimplementasikan sebagai landasan gerak atau kiprah Muhammadiyah dalam bidang politik. Dimensi komunikasi politik Muhammadiyah diantaranya: ${ }^{24}$

1. Dimensi ijtihad dan tajdid dengan landasan pokok alQur'an dan al-Sunah sehingga Muhammadiyah berwatak non-mazhab.

2. Aktualisasi cita perjuangan melalui sistem organisasi sehingga Muhammadiyah mengangkat kepentingan dan keselamatan pribadi ke wilayah kepentingan sosial.

3. Corak 'anti-kemapanan' terhadap lembaga keagamaannya pada wilayah praksis-sosial.

4. Adaptif terhadap tuntutan perubahan zaman sehingga membuat Muhammadiyah lincah dalam memperjuangkan aspirasi dan mempertahankan prinsip dasar perjuangannya dalam berbagai era perubahan sosial di Indonesia.

Strategi kultural yang berorientasi keagamaan (religius) juga tampak dari posisi Muhammadiyah sebagai gerakan tajdid. Tajdid memiliki makna pembaharuan, inovasi, restorasi, modernisasi, dan kata lain yang sebangun. Sebagai gerakan tajdìd maka Muhammadiyah melakukan upaya memperbaharui pengertian kaum muslimin mengenai agamanya, mencerahkan hati dan pikiran umat dengan cara mengenalkan kembali ajaran Islam sejati yang bersumber pada al-Qur’an dan al-Sunnah. ${ }^{25}$

Menurut pengamatan penulis, warna agama menjadi khas dalam perjalanan politik Muhammadiyah, tidak berbeda dengan semua kekuatan sosial politik di Indonesia, khususnya partai-partai Islam telah menggunakan agama sebagai kendaraan politik yang ditungganginya. Penilaian ini diperkuat realitas politik dengan hadir sejumlah elite politik Muhammadiyah, selain identik dengan tradisi khas komunitas pesantren, dengan menggunakan kacamata politik, Muhammadiyah juga dapat dengan mudah dapat diidentifikasi sebagai komunitas politik.

24 Suwarno, Muhammadiyah Sebagai Oposisi, (Jogjakarta: UII Press, 2001), h. 63.

25 Suwarno, Muhammadiyah Sebagai Oposisi, h. 23.

112 Jurnal a l-Amin, Volume 3, No 1, 2015 M/1436 H 
Dimensi politik gerakan Muhammadiyah tidak bisa diabaikan. Tidak sedikit kontribusi yang telah diberikan oleh organisasi politik yang cukup serius. Pertanyaan tentang adakah budaya politik Muhammadiyah?. Dalam konteks ini saya cenderung untuk melihat fenomena kemunculan Muhammadiyah tahun 1912 sebagai representasi dari gerakan kaum muslim kota yang berupaya merumuskan: pertama, jati dirinya dalam konteks keagamaan maupun agenda kebangsaan. Kedua, merumuskan identitas masyarakat atau bangsa yang hendak ditegakkan dan dibangun. Dua hal ini menjadi penting antara lain karena ini sekaligus menunjukkan keseriusan organisasi ini untuk menawarkan ideologi yang dianggap tepat bagi masyarakat maupun bangsa. Dalam kaitan ini maka paling tidak ada tiga fase perkembangan Muhammadiyah:

Pertama, fase identifikasi diri. Pada fase ini, sebagai bagian dari rivalisme Islam awal abad XX, Muhammadiyah menampilkan dirinya sebagai gerakan Islam modern yang berbasis perkotaan dan menjanjikan perubahan. Pilihanpilihan strategis yang digarap Muhammadiyah: agama, sosial, pendidikan fase ini dimaksudkan untuk merevitalisasi Islam secara kultural sehingga diharapkan bisa menjadi sebuah landasan kerja yang kukuh dan sistematis bagi citacita politik Islam secara umum. Pada fase yang oleh Din syamsuddin disebut sebagai The Revitalization of Islamic Culture ini Muhammadiyah secara bertahap telah berhasil memperoleh dukungan yang cukup luas. Atas dukungan basis massa inilah Muhammadiyah mulai menemukan bentuk dan mengeksposisi 'umat'nya: sebuah model umat yang menggabungkan secara kritis dan rasional unsur Barat dan Islam. Tawaran ini sudah barang tentu lebih bisa diterima oleh kaum rasionalis Muslim kota ketimbang oleh kaum tradisionalis Muslim yang cenderung memperawet tradisi, dan bahkan juga oleh kelompok sekular.

Kedua, fase ideologi-politik. Basis massa yang telah terbangun atas dasar Islam ini merupakan legitimasi terhadap keterlibatan elite Muhammadiyah secara praktis dalam politik sekaligus merumuskan Islam sebagai ideologi politik. Hampir bisa dikatakan bahwa para tokoh Muhammadiyah lebih cenderung beraliansi dengan kelompok 'sosialis religius' (untuk meminjam kategori K. E. Ward ketika bicara tentang pengelompokan dalam Masyumi). Hal ini karena sikap maupun pandangan kelompok ini memang 
sesuai dengan watak dasar keagamaan Muhammadiyah. Seperti yang telah terungkap dalam catatan sejarah bahwa tuntutan kelompok ini adalah tegaknya satu bentuk masyarakat sosial-ekonomi dan politik Indonesia modern tang didasarkan kepada ajaran Islam (syariat Islam). Semangat ini sesuai dengan idealisme Muhammadiyah yang berupaya mewujudkan 'masyarakat Islam yang sebenarbenarnya' atau 'masyarakat utama'. Dengan demikian keterlibatan Muhammadiyah atau sejumlah tokoh Muhammadiyah mendirikan Partai Islam Indonesia (PII), MIAI, kemudian dalam BUPKI serta Masyumi dan Parmusi merupakan representasi semangat menegakkan ideologi dan politik Islam yang khas di Indonesia. Tentunya, sebagaimana yang sudah disebut di atas, karena argumen-argumen tertentu mereka berhadapan dengan para pertentangan yang terdiri dari kaum nasionalis sekular, non-Islam dan bahkan dari kelompok Muslim tradisionalis (kategori Deliar Noer). Perdebatan ideologi dan juga tensi politik ini mewarnai setting politik nasional BUPKI hingga tumbangnya Orde Lama. Tidak heran jika kekuatan Islam pada era ini dilihat sebagai faktor ancaman potensial. Dan posisi Muhammadiyah, yang pada waktu itu menjadi anggota istimewa Masyumi, menjadi sulit. Namun demikian, kesulitan-kesulitan politik ini tidak mengganggu untuk melangsungkan proyek-proyek sosial, agama dan pendidikan, karena memang inilah yang menjadi inti gerakan Muhammadiyah.

Ketiga, era depolitisasi dan ideologisasi. Tumbangnya komunitas dan tegaknya Orde Baru sebenarnya memberikan harapan termasuk bagi Muhammadiyah untuk melanjutkan perjuangan politiknya. Peluang ini memang diberikan akan tetapi dengan catatan harus mengikuti logika restrukturisasi politik orde baru dalam rangka stabilitas dan pembangunan nasional. Ini artinya bahwa Muhammadiyah pada akhirnya harus menerima kenyataan bahwa ideologi politik Islam sebagaimana yang selama ini diperjuangkan mesti segera dikubur. Di samping itu Muhammadiyah dan kekuatan ormas lainnya harus secara tepat melakukan proses 'penyesuaian politik'; pragmatisme politik mesti menjadi satu-satunya pilihan sikap yang harus diambil oleh Muhammadiyah. Selanjutnya bahwa pada era ini, terutama sejak tahun 1971, politik lebih merupakan pilihan dan tanggung jawab individual ketimbang menjadi wilayah 
garapan secara formal Muhammadiyah. Pola keterlibatan tokoh Muhammadiyah dalam politik telah bergeser dari 'mewakili lembaga' ke 'mewakili diri'; dari ketergantungan kepada kekuatan lembaga menjadi mengandalkan kepada kekuatan dan kemampuan diri. Pergeseran pola kekuatan ini cukup berpengaruh paling tidak mendorong kemunculan 'pelobi Muhammadiyah' yang cukup andal semacam Lukman Harun atau Din Syamsuddin misalnya.

Keempat, repolitisasi. Era depolitisasi dan deideologisasi Muhammadiyah ini semakin memperoleh bentuknya tentu sejak penerapan Pancasila sebagai satusatunya asas. Namun demikian, fenomena kebangkitan kultural Islam yang antara lain juga dikarenakan semakin tidak populernya politik atau partai Islam, tampaknya justru juga menyuburkan semangat repolitisasi di lingkungan masyarakat Muhammadiyah. Tidak sedikit tokoh Muhammadiyah atau yang merasa memiliki hubungan emosional dengan Muhammadiyah adalah aktivis orsospol. Mayoritas tampaknya di Golkar. Faktornya: (1) Mayoritas warga Muhammadiyah adalah pegawai negeri. Penampilan kultural yang impresif dari Muhammadiyah telah mendorong sejumlah pembesar negeri (termasuk presiden sendiri) untuk menyatakan secara terbuka bahwa mereka adalah 'orang Muhammadiyah'. Hal ini menjadi faktor mobilisasi warga Muhammadiyah untuk melakukan 'ittibā' politik' kepada pembesar. (3) keterlibatan mereka dalam kekuatan politik ini dinilai strategis antara lain untuk semakin menyuburkan penghijauan politik, atau dalam bahasa Muhammadiyah disebut sebagai 'dakwah bi alhikmah'. Ini tidak berarti bahwa PPP terabaikan. Tarik menarik sejumlah tokoh dan kaum muda Muhammadiyah menjelang Muktamar PPP beberapa waktu yang lalu sebetulnya cukup intens. Hanya karena tidak terekspos, maka tidak mengganggu perjalanan Muhammadiyah. Seandainya tarik menarik tersebut muncul di permukaan, maka tidak ada bedanya antara Muhammadiyah dengan NU.

Ada beberapa faktor tampaknya yang ikut mendorong repolitisasi ini: (1) untuk membunuh apatisme akibat kekecewaan dan perceraiannya dengan politik tahun 1971. (2) untuk mempertegas dimensi politik dari kebangkitan kultural Islam yang selama beberapa tahun belakangan ini bergerak secara impresif. (3) adanya kesadaran bahwa ternyata tidak sedikit kelompok sosial yang termarginalisasi 
secara ekonomi-politik. Akumulasi ekonomi-politik selama ini banyak terkonsentrasi di kelompok-kelompok tertentu saja. (4) sistem politik yang diharapkan tampaknya dinilai belum cukup secara maksimal mendorong terwujudnya perimbangan kekuatan yang ideal, keterbukaan politik, demokrasi dan keikutsertaan masyarakat secara maksimal.

Namun demikian, hal lain yang tampaknya patut direnungkan adalah bahwa tidak seperti era ideologi politik pada era ini, kelihatannya Muhammadiyah lebih banyak bergantung kepada kepiawaian para pelobinya. Dan ini artinya jika Muhammadiyah tidak memiliki pelobi, maka takkan berjalanlah fungsi-fungsi dakwah bi al-hikmahnya.

Mencermati watak budaya dan keagamaan Muhammadiyah, perjalanan dan pola hubungan Muhammadiyah politik serta agenda demokratisasi dan isuisu lainnya, maka hemat penulis Muhammadiyah mesti melakukan pilihan-pilihan strategis, tanpa harus terlibat secara praktis dalam politik dan tetap memberikan kebebasan secara bertanggung jawab kepada seluruh warganya untuk menentukan pilihan-pilihan politiknya, Muhamamdiyah perlu mencermati aspek-aspek strategis dari kehidupan berbangsa ini sembari merumuskan secara tepat model dakwah bi al-hikmah seperti apakah semestinya dikembangkan sehingga 'Masyarakat Utama' bisa menjadi model alternatif. ${ }^{26}$

Fenomena politik yang diwarnai muatan agama, telah menjadi saluran komunikasi Muhammadiyah, selain komunikatornya adalah sosok pemuka agama, dan momentum yang menjadi salurannya yaitu sesuai dengan khittahnya dakwah 'amar ma'rūf dan nahyi munkar, dalam arti dan proporsi yang sebenar-benarnya.

Selain itu, nuansa agama juga dapat melekat pada dimensi media. Fungsinya sama untuk mempermudah proses komunikasi sekaligus meningkatkan kualitas efek yang ditimbulkannya. Dengan meminjam kategorisasi sistem dasar beroperasi dalam transaksi komunikasi Dedy Mulyana, dimensi media ini termasuk pada sistem eksternal yang meliputi unsur-unsur dalam lingkungan di luar individu. ${ }^{27}$

26 Sudarnoto Abdul Hakim, Kultural dan Politik Muhammadiyah, (Jakarta: Perkasa, 1995), h. 88-91.

27 Deddy Mulyana, Imu Komunikasi Sebagai Suatu Pengantar, (Bandung: Remaja Rosdakarya, 2001), h. 106.

116| Jurnal a 1-Amin, Volume 3, No 1, 2015 M/1436 H 
Muhammadiyah sebagai gerakan dalam mengikuti perkembangan dan perubahan itu, senantiasa mempunyai kepentingan untuk melaksanakan amar ma'rüf dan nahyi munkar, serta menyelenggarakan gerakan dan amal usaha yang sesuai dengan lapangan yang dipilihnya, ialah memasyarakat, sebagai usaha Muhammadiyah untuk mencapai tujuannya, menegakkan dan menjunjung tinggi agama Islam sehingga terwujud masyarakat utama adil dan makmur yang diridhai Allah Swt. Hal tersebut dipandang sebagai jembatan yang menghubungkan pertalian agama dengan politik.

Dalam melaksanakan usaha tersebut Muhammadiyah berjalan di atas prinsip gerakannya seperti yang dimaksud di dalam keyakinan dan cita-cita hidup Muhammadiyah.

Keyakinan dan cita-cita hidup Muhammadiyah senantiasa menjadi landasan gerakan Muhammadiyah juga bagi amal usaha dan hubungannya dengan kehidupan masyarakat dan ketatanegaraan, serta dalam kerja sama dan golongan Islam lainnya. 28 Dalam hal ini respons media terhadap isu tersebut cukup besar dengan menurunkan landasan gerakan tersebut dalam nuansa yang sangat politis, dengan menekankan kesan sebagai bentuk komunikasi politik warga Muhammadiyah.

Penggunaan kerangka teoretis dalam proses komunikasi politik yang menempatkan dominasi otoritas elite Muhammadiyah, baik secara institusional maupun individual sebagai faktor determinan dalam pola dan perilaku serta komunikasi politik Muhammadiyah. Konstruksi komunikasi secara institusional dibangun atas otoritas yang dimiliki para pengurus struktural atau organisatoris Muhammadiyah, setiap kebijakan dan pesan politiknya didasarkan pada keputusan organisasi. Sementara secara personal, otoritas yang dimiliki ulama karismatik dengan segala pengaruhnya menempati posisi komunikator elitis, sehingga pesan politiknya dapat diterima baik komunikan Muhammadiyah. Tinggi rendahnya partisipasi politik Muhammadiyah tidak lepas dari pengaruh faktor determinasi

28 Badan Pendidikan Kader Pimpinan Pusat Muhammadiyah Tahun, "Perkaderan Muhammadiyah Hakikat Islam, Metodologi Pemahaman Islam Sejarah Gerakan Pembaharuan Muhammadiyah Sebagai Gerakan Islam, Kapita Selekta, Strategi Perjuangan Muhammadiyah", tt.p.: 1415 H/1994 M), h. 205. 
elite Muhammadiyah tersebut. Faktor determinasi dari otoritas, keelitan dan karisma elite NU, selaku komunikator dalam menyampaikan pesan-pesan politik, memberi pengaruh atau efek yang signifikan. Figur ulama senantiasa memiliki otoritas karismatik sehingga selalu menjadi sorotan, tidak terkecuali dalam konteks politik.

Dari penjelasan yang telah dikemukakan, Almond menyatakan bahwa terdapat tiga model dalam kebudayaan politik atau model orientasi terhadap pemerintahan dan politik diantaranya:

1. Masyarakat demokratis industrial. Dalam sistem ini terdapat cukup banyak aktivis politik yang meminjam kompetisi partai-partai politik dan kehadiran pemberi suara yang besar. Selain itu, juga banyak peminat politik yang selalu mendiskusikan secara kritis tentang moral kemasyarakatan dan pemerintahan, kelompok-kelompok yang selalu mengusulkan kebijaksanaan-kebijaksanaan baru dan melindungi kepentingan khusus mereka.

2. Sistem Otoriter. Dalam model ini terdapat beberapa kelompok masyarakat yang memiliki sikap politik yang berbeda. Kelompok organisasi politik dan partisipan politik, mahasiswa dan kaum intelektual yang berusaha menentang dan mengubah sistem melalui tindakan persuasif atau protes yang agresif.

3. Sistem demokratis preindustrial. Dalam negara dengan model seperti ini, hanya sedikit sekali persiapan yang terutama dari profesional dan pengusaha. Sejumlah warga negara, seperti pegawai buruh, petani yang buta huruf, memiliki pengetahuan dan keterlibatan dalam kehidupan politik yang sangat kecil. ${ }^{29}$

Dari apa yang ditegaskan Almond tersebut dapat diketahui bahwa basis budaya komunikasi Muhammadiyah secara substantif mempunyai hubungan timbal balik, seperti dua sisi mata uang. Budaya menjadi bagian dari perilaku komunikasi yang pada gilirannya komunikasi pun turut menentukan, memelihara, mengembangkan atau mewariskan budaya. Budaya komunikasi Muhammadiyah, pada dasarnya merupakan salah satu perwujudan efek

29 Gabriel Almond dalam Muchtar Mas'oed dan Colin MacAndrew, Perbandingan Sistem Politik, (Yogyakarta: Gadjah Mada University, 1982), h. 39.

118| Jurnal a l-Amin, Volume 3, No 1, 2015 M/1436 H 
hubungan timbal balik dari proses konvergensi antara budaya yang melekat pada setiap anggota komunitas itu dengan kebutuhan komunikasi dalam proses interaksi sosial yang dilaluinya.

Proses komunikasi sosial yang berlangsung secara kultural maupun struktural telah mengantarkan organisasi massa Islam terbesar di Indonesia ini pada realitas politik seringkali dinilainya dilematis. Berkaitan dengan realitas tersebut, terdapat beberapa unsur komunikasi yang menyiratkan fungsinya yang masih belum jelas diketahui. Terutama, keterkaitan antara proses komunikasi dengan sikap dan komunikasi politik di lingkungan Muhammadiyah.

Komunikasi politik dalam Muhammadiyah implikasinya akan menyentuh batasan komunikasi politik, yang akan berbeda dengan batasan politik pertama dan kedua. Pada batasan pertama, politik lebih ditekankan pada serangkaian tindakan yang mengarahkan dan menata urusan-urusan publik yang dapat diperankan oleh siapa pun, asalkan dia warga dari ruang publik tersebut. Muhammadiyah adalah salah satu elemen dari ruang publik Indonesia, mereka menerima sejumlah kebijakan politik dari kekuasan negara dan meresponsnya sesuai dengan tradisi organisasi mereka sendiri. Kekhasan suatu organisasi menentukan komunikasi politik yang digunakannya. Dalam melakukan komunikasi politik, seorang elite Muhammadiyah harus mampu memainkan peranan yang amat penting di dalam suatu sistem politik karena menjadi bagian yang menentukan dari proses sosialisasi politik, budaya politik, partisipasi politik, dan rekrutmen politik. Maka itu, dalam organisasi massa semacam Muhammadiyah pemeranan komunikasi politik dapat juga dilakukan oleh pemimpin karismatik dengan kekhasan tertentu yang dimilikinya.

Dengan demikian, komunikasi politik Muhammadiyah berdiri di antara dua kepentingan, satu sisi meneruskan informasi politik dari atas ke bawah, dan di sisi lain mengemukakan kepentingan rakyat atau umat ke pihak kekuasaan. 


\section{DAFTAR PUSTAKA}

A. Mukti Ali, Interpretasi tentang Amalan Muhammadiyah, dalam Pegangan Instruktur Kaderisasi Pemuda Muhammadiyah, Jakarta: Pimpinan Pusat Pemuda Muhammadiyah, 1982.

Afan Gaffar, Bahan Kuliah Analisa Politik Indonesia.

, Budaya Politik Indonesia, Bahan Kuliah Analisa Politik Indonesia, Yogyakarta: Program Pascasarjana Ilmu Politik UGM, 1998.

----------, Politik Indonesia Transisi Menuju Demokrasi.

Ahmad Syafii Ma'arif, Independensi Muhammadiyah: Di Tengah Pergumulan Pemikiran Islam dan Politik, Jakarta: Cidesindo, 2000.

Badan Pendidikan Kader Pimpinan Pusat Muhammadiyah, "Perkaderan Muhammadiyah Hakikat Islam, Metodologi Pemahaman Islam Sejarah Gerakan Pembaharuan Muhammadiyah Sebagai Gerakan Islam, Kapita Selekta, Strategi Perjuangan Muhammadiyah", tt.p.: $1415 \mathrm{H} / 1994 \mathrm{M}$.

Deddy Mulyana, Ilmu Komunikasi Sebagai Suatu Pengantar, Bandung: Remaja Rosdakarya, 2001.

Delier Noer, The Modernist Muslim Movement in Indonesia 1900-1904, London: Oxford University Press, 1973.

Gabriel A. Almond, Sosialisasi, Kebudayaan dan Partisipasi Politik, dalam Mohtar Mas'oed dan Colin Mac Andrews (editor). Perbandingan Sistem Politik, Yogyakarta: Gadjah Mada University Press, 1995.

Haedar Nasir, Revitalisasi Gerakan Muhammadiyah, Yogyakarta: BIGRAF Publishing, 2000.

James L. Peacock, Gerakan Muhammadiyah Memurnikan Ajaran Islam di Indonesia, Jakarta: Cipta Kreatif, 1986.

Kusnanto Anggoro, Rekonstruksi dan Reorientasi Budaya Politik, dalam J. Soedrajati Djiwandono dan T.A. Legowo (Penyunting), Revitalisasi Sistem Politik Indonesia, Jakarta: CSIS, 1996. 


\section{Pia Khoirotun Nisa}

M. A. Gani, Cita Dasar Pola Perjuangan Syarikat Islam, Jakarta: Bulan Bintang, 1984.

M. Cholil Bisri, Nahdlatul Ulama: Proses Kristalisasi atau Ketuaan, dalam Wahid, Republika: t.p., 1995.

M. Daris Tamim, Muhammadiyah di Mata Rantai Perjalanan Bangsa, dalam Suara Muhammadiyah No. 22/67 tahun 1987.

Nurcholish Madjid, Aqidah Islam Yang perlu Dikembangkan Sebagai Landasan Pemikiran dan Amal Muhammadiyah, dalam Sujarwo (dkk) Muhammadiyah dan Tantangan Masa Depan: Sebuah Dialog Intelektual, Yogyakarta: Tiara Wacana, 1990.

Roeslan Abdulgani, Peranan Muhammadiyah dalam Pergerakan Nasional dan Kemungkinan Masa Depannya, dalam M. Yunan Yusuf, Cita dan Citra Muhammadiyah, Jakarta: Pustaka Panjimas, 1985.

Sudarnoto Abdul Hakim, Kultural dan Politik Muhammadiyah, Jakarta: Perkasa, 1995.

Sutrisno Kutoyo, Kiai Haji Ahmad Dahlan dan Persyarikatan Muhammadiyah, Jakarta: Balai Pustaka, 1998.

Suwarno, Muhammadiyah Sebagai Oposisi, Jogjakarta: UII Press, 2001.

Taufik Abdullah, Muhammadiyah dalam Perspektif Sejarah, dalam Tim Pembina al-Islam dan Kemuhammadiyahan, Muhammadiyah: Sejarah, Pemikiran dan Amal Usaha, Malang: Pusat Dokumentasi dan Publikasi Universitas Muhammadiyah Malang, 1990. 